\title{
Arbor
}

\section{Familia e identidad masculina}

\author{
Enrique Gil Calvo
}

Arbor CLXXIV, 685 (Enero 2003), 53-75 pp.

El objetivo que me mueve al abordar las relaciones entre la institución familiar y la identidad masculina no es el de inscribirme dentro de la tradición abierta por Elisabeth Badinter ${ }^{1}$, cuando caracterizó (si es que no caricaturizó) una presunta identidad de género, socialmente construida, que debiera ser atribuida a todos los varones occidentales por igual, en la medida en que se les invita a reconocerse en ella y a realizarla en su propia trayectoria personal; para luego, a partir de allí, analizar las consecuencias que para el desempeño de los papeles de hijo, hermano, novio, marido, padre, tío, abuelo, etc, se derivarían de la existencia de semejante identidad colectiva. Y si no deseo abordar ahora esa línea es porque ya la seguí antes, cuando traté de profundizar en un libro sobre las quiebras y contradicciones que afectan a la deriva contemporánea de la identidad masculina ${ }^{2}$.

No, mi propósito actual es otro. Como la existencia real de una presunta identidad común a todos los varones me parece más que dudosa, prefiero utilizar el término identidad de otra forma bien distinta. En lugar de una suerte de esencia colectiva más o menos determinista que se les impondría a todos los hombres desde fuera, viéndose obligados a encarnarla y hacerla suya, prefiero proponer un modelo mucho más plural de múltiples identidades masculinas, entre las que cada varón se vé obligado a optar de acuerdo a su libre elección personal. Para justificar este planteamiento pluralista cabe acogerse a la autoridad intelectual de Jon Elster, partiendo de su concepto de yo múltiple ${ }^{3}$. Pero esta multiplicidad de identidades alternativas también se puede asociar con el cruce o intersección de identidades plurales de que hablan muchas autoras posfeministas, como Judith Butler ${ }^{4}$. Y en este sentido, 
el propósito de mi intervención bien pudiera ser el de deconstruir la identidad colectiva masculina (como gustan hacer los posmodernos cultural studies anglosajones), descomponiéndola en sus diversas variantes o dimensiones constitutivas.

No obstante, el repertorio de yoes múltiples en cuya intersección se sitúa cada varón es muy variado, dependiendo de su ciclo de vida, de su experiencia cultural, de su posición familiar y de su anclaje en la estructura social. Por lo tanto, para no hacer la cuestión excesivamente compleja, reduciré la variabilidad del yo masculino a una tipología muy sencilla, vinculada al desarrollo biográfico de la propia identidad, y que consta de sólo tres tipos ideales opuestos entre sí, tal como son reconocibles en la tradición cultural europea: son los arquetipos del Padre, el Hijo y el Espíritu: aunque no sólo santo, necesariamente.

\section{La trinidad masculina}

La tipología triádica que propongo procede de múltiples fuentes mitológicas o literarias. Una de las más conocidas es quizá la derivada del panteón trinitario reconocible en todas las religiones indoeuropeas (arias, védicas, escandinavas, celtas o grecolatinas), tal como fueron comparativamente analizadas por Georges Dumézil, quien dedujo a partir de ellas su teoría de las tres funciones de la divinidad. La primera función es el ejercicio soberano del poder espiritual, monopolizado por los dioses supremos de la sabiduría, que cabe identificar con el cristiano Espíritu Santo. La segunda función es el valor heroico que concede la victoria en la lucha militar, protagonizada por los dioses de la guerra que se asocian a los héroes inmortales vinculados con la figura cristiana del Hijo como Mesías, Rey de Reyes o Señor de los Ejércitos. Y la tercera función es la creación de riqueza material, sumistrada por las divinidades de la fortuna y la fecundidad, a las que también cabe identificar con el Padre Providencial de la Trinidad cristiana.

Otra tríada ideológica semejante y relacionada con la anterior es la bien conocida distinción medieval entre los tres órdenes feudales de oratores (que rezan para salvar a la comunidad), bellatores (que combaten para protegerla con sus armas) y laboratores (que trabajan para alimentarla). De esta triple partición salió la sociedad del Antiguo Régimen, dividida en los tres estados que posteriormente se designarían con los términos de clero, nobleza y tercer estado (que englobaba por 
igual a campesinos, burgueses y menestrales o villanos) ${ }^{5}$. Como es evidente, semejante trinidad estamental se corresponde exactamente con las tres funciones indoeuropeas de Dumézil y con la trinidad cristiana.

Pero quizá resulta preferible fundarse en otra tipología triádica todavía más influyente, y que además resulta lógicamente anterior, pues pretende constituir el fundamento antropológico universal sobre el que están construidas todas las diversas mitologías literarias o folklóricas. Me refiero al pensamiento salvaje reconstruido por el célebre etnólogo estructuralista Claude Lévi-Strauss, quien encuentra en sus Mitológicas un substrato común a todas las formas de clasificación, resumidas en su famoso triángulo alimentario, que distingue entre lo crudo, lo podrido y lo cocinado. En efecto, toda cultura humana clasifica a sus alimentos así, según que estén verdes, inmaduros o sin transformar, en cuyo caso se les llama crudos; según que estén transformados por la naturaleza, en cuyo caso se les tiene por excesivamente maduros, podridos o corrompidos; o según que estén transformados por la cultura, en cuyo caso se les toma por alimentos legítimamente cocinados ${ }^{6}$.

Pues bien, dado que los seres humanos necesitan alimentarse para crecer hasta hacerse a sí mismos, y que su desarrollo es una transformación tanto natural como cultural, este mismo triángulo de LéviStrauss puede aplicarse también al proceso de maduración de las personas, desde que nacen hasta que alcanzan su pleno desarrollo. Los menores de edad son seres inmaduros, que carecen todavía de derechos por estar aún verdes o demasiado crudos. Es el primer polo del triángulo, correspondiente a las personas que están todavía sin hacer, en transición o pendientes de desarrollo. Pero al crecer, esos menores se transformarán en adultos, a los que hay que clasificar en dos polos opuestos: los adultos legítimos que han madurado correctamente, de acuerdo a las normas culturales prescritas por su sociedad, frente a los adultos ilegítimos que han madurado de forma monstruosa, al margen de la cultura o de acuerdo a su perversa naturaleza.

Ahora bien, según cuál sea el género (o el sexo) de los seres humanos, su proceso de legítima maduración da lugar a triángulos lévistraussianos opuestos. En el caso de las mujeres, la tríada crudo-cocido-podrido da lugar a la trinidad virgen-madre-puta, mientras que en el caso de los hombres da lugar al trinomio héroe-padre-monstruo. Respecto al triángulo femenino, no es este lugar para desarrollarlo, sobre todo teniendo en cuenta que ya le he dedicado a la cuestión un libro entero ${ }^{7}$, donde analicé los ejes sintácticos (de maduración sexual, legitimidad cultural y sujeción social) que definen los tres arquetipos de la Virgen (la Doncella guerrera y espiritual, la Heroína andrógina), la Madre (la esposa le- 
gítima, la Señora de la casa, la noble y casta Dama) y la Puta (la perra lujuriosa, la hija seducida, la madre soltera, la esposa adúltera, la bruja sacrílega, la celestina corruptora). Y en esa misma obra propuse una traducción de este modelo a la imagen masculina, pero con dudosos resultados, que aquí cabe revisar en profundidad.

Si relacionamos las tres funciones mitológicas de Dumézil con el triángulo de Lévi-Strauss, obtendremos una tríada masculina de tres vértices, comparable con la femenina pero que también evoca a la Trinidad cristiana. La figura inmadura de la Virgen o Doncella se corresponde en el caso masculino con la del Dios-Hijo y con la del no menos inmaduro Héroe de los relatos épicos o novelescos: un personaje incompleto que está en trance de hacerse a sí mismo, si supera con éxito pruebas iniciáticas, cruciales calvarios redentores, arduas luchas por la vida y esforzados agonismos dramáticos que ponen su valor en juego. En este polo inicial del triángulo masculino es donde aparecen los imposibles trabajos de Hércules que el héroe debe resolver con éxito y la hybris prometeica o furor del guerrero de que habla Dumézil, así como la tarea del héroe cantada por Fernando Savater ${ }^{8}$.

Pero cuando el joven Héroe incompleto supera por fin las pruebas o trabajos a realizar, coronando con éxito su pasión sacrificial, deja de ser un Hijo y se convierte en un Padre entero y eterno, en tanto que auténtico Hombre completo, hecho y derecho. $\mathrm{Y}$ esta conversión del Hijo en sucesor de su Padre cierra el ciclo masculino de maduración legitima. Como afirma el campesino que protagoniza la biografía realizada por Frigolé, un verdadero hombre no es un mero domador de mujeres sino alguien capaz de fundar una familia y sacarla ${ }^{9}$ adelante. Esta figura patrimonial del Padre se corresponde con la matrimonial de la Madre, como es evidente, pero también evoca el patronazgo patriarcalista de la divina providencia, pues el padre-padrone es un fundador de familias, en tanto que fecundo autor de los días de sus hijos, a quienes reconoce o deniega su plena legitimidad sucesoria.

Queda el tercer vértice masculino del triángulo lévistraussiano, de difícil identificación. La corrupción de la legítima trayectoria femenina que ha de conducir desde la joven hija e inmadura doncella hasta la dama madura, madre de familia y señora de su casa, parece muy clara, pues esa ilegítima desviación está plenamente ocupada por la Zorra, la Bruja o la Puta. Pero ¿y en el caso de los hombres?: ¿cuál es la figura que mejor representa su camino de podredumbre y perdición?

Me gustaría proponer aquí la figura del Monstruo como tercer tipo de masculinidad ilegítima, desviada o perversa. Y digo «monstruo» en el triple sentido de deformación contrahecha, que impide completar 
la adulta forma madura (como Polifemo, que parece monstruoso por tener solo un ojo en la cara), de hibridación inviable entre formas antitéticas (como en las órdenes religiosas de monjes-soldados «monstruosamente» consagrados ${ }^{10}$ a derramar sangre con su espada), y de excepcionalidad, metamorfosis o mutación congénita (como se dice del artista extraordinariamente dotado que es un monstruo de la naturaleza). Por eso es a la vez un ogro y un artefacto hecho de retazos, como el creado por Frankenstein, que se parece a un ornitorrinco o a un cyborg: ser mixto, mitad robot cibernético, mitad organismo natural ${ }^{11}$.

La característica esencial del monstruo es su excepcionalidad, pues se trata de un ser liminar, situado más allá de los límites del orden social cotidiano cuyas deficiones de la realidad viene a transgredir, porque no le contienen ni por tanto le comprenden. De ahí que su naturaleza sea ritual ${ }^{12}$ y que aparezca como sagrado (o sacrílego y profanador, que viene a ser lo mismo), en términos de Durkheim. O como carismático, en palabras de Weber, pues el monstruo parece poseer mana: esa virtud o gracia extraordinaria que le confiere a ojos de sus seguidores el carisma de un ser superior o sobrenatural.

Eso hace del monstruo tanto una rareza como un ser anormal o desviado, que le convierten a los ojos de la comunidad en un extraño. Y su misma extrañeza le confiere tanta visibilidad que no puede pasar desapercibido, llamando poderosamente la atención. De ahí que su presencia resulte ante todo notoria e inquietante, casi escandalosa, para resultar en seguida amenazadora y peligrosa, lo que despierta intensas reacciones emocionales de fascinado rechazo. En consecuencia, pronto estalla la violencia a su paso, pues su misma singularidad original le hace erigirse en catalizador de todos los conflictos que laten en su torno, a los que aviva y realimenta como si los encendiese por pura provocación espontánea. Y así es como el extraño se convierte en un chivo expiatorio: un monstruo al que culpar de todos los males reales o imaginarios. Es decir, un monstruo al que se debe sacrificar en bien de la comunidad, para poder redimirla y salvarla ${ }^{13}$.

He aquí la definición de monstruo que, refiriéndose al Moby Dick de Herman Melville, propone el escritor argentino César Aira ${ }^{14}$ : «una especie que consta de un sólo individuo», cuya muerte acarrea la extinción de su estirpe. Por eso el Monstruo se opone al Padre, pues, al ser congénitamente estéril, carece de progenie, no puede nombrar sucesores y es incapaz de fundar familias. Pero, según observa el mismo César Aira, aunque no tenga herederos, el Monstruo sí posee un antagonista privilegiado, pues «resulta infalible que haya un cazador obsesionado con él: su sombra, su gemelo humano, su némesis». Es 
el Héroe cazador de monstruos, como Teseo enfrentado al Minotauro, Ulises a Polifemo o San Jorge al Dragón, a los que debe desafíar y perseguir para poderlos vencer y destruir. De este modo se cierra el triángulo de oposiciones binarias previsto por Lévi-Strauss, pues el Monstruo es tanto la antítesis del Héroe, con el que forma una simbiosis indiscernible de Angel o Demonio, como la del Padre, cuya fecundidad providencial y sucesoria está fuera de su alcance.

Pero ¿cómo podría aplicarse a la identidad masculina esta definición de la figura del monstruo que acabo de sugerir? Si regresamos a LéviStrauss, advertiremos que su triángulo culinario simple o primario (que divide a los alimentos en crudos, cocinados o podridos) se puede desenvolver en ulteriores triángulos más complejos o desarrollados, que se derivan del triángulo original. Así, el vértice de lo cocinado contiene a su vez un nuevo triángulo de géneros de cocina, donde lo menos cocinado es el vértice de lo asado, lo más cocinado sin ingredientes naturales es lo ahumado (lo curado, lo salado) y lo más cocinado con ingredientes naturales (como el agua) es lo cocido: la olla podrida, el pot pourri. Pues bien, apliquemos al género masculino que hemos identificado, el de los monstruos, este triángulo desarrollado.

\section{Sublimación del monstruo}

¿Qué tipología de monstruos nos aparecen? El menos cocinado por la cultura es el ingenuo salvaje: el perverso polimorfo de Freud, que desea todo y lo desea ahora. Se trata, pues, de un monstruo natural o libidinoso, relacionado con el culto a Príapo y a Dionisos, asociado a las metamorfosis animales que utiliza Zeus para seducir a sus víctimas, y representado tanto por el fauno rijoso y el tenorio casanova como por el gay promiscuo y el sátiro pederasta. Pero debe quedar claro que su actividad, por transgresora e ilegal que resulte, es la de un mero depredador parasitario, que sólo ejerce actividades monstruosas (como violar, seducir o defraudar) por puro amor al arte de hacerlo, sin proponerse ninguna otra finalidad ulterior. Su monstruosidad es, pues, expresiva, espontánea y gratuita (hedonista, deportiva, esteticista), pero nunca interesada, utilitaria ni instrumental.

Sin embargo, conforme la cultura y su propia naturaleza van transformando a este inmaduro monstruo compulsivo, se desarrolla y convierte en un monstruo reflexivo y consciente de sí, capaz por tanto de proponerse fines, calcular los medios mejores para alcanzarlos y 
adquirir la firma voluntad de conseguirlos. Ahora bien, según cuáles sean los fines que se proponga cumplir, si legítimos (es decir, fundados en el reconocimiento y la reciprocidad de los derechos) o ilegítimos (atentatorios contra los derechos ajenos), el monstruo maduro pertenecerá a uno u otro de estos dos géneros: el monstruo tanático que sólo busca el Mal, y el monstruo sublimado que puede hacer el Bien.

El monstruo tanático (vértice podrido e ilegítimo del triángulo de la monstruosidad masculina) es el Matador, el Maligno o el Monstruo propiamente dicho, en sentido restringido. La antigüedad grecorromana y la cultura popular premoderna no pudieron concebir ninguna figura personal singular para representar el $\mathrm{Mal}$ absoluto, al que se identificaba con los Hados o las Moiras, como plurales agentes del aciago pero anónimo destino fatal. Pero a cambio existía una variada multitud de monstruos malignos menores, por el estilo de ogros y cíclopes, genios perversos y malvados diablos, malos espíritus y gigantes descomunales, todos ellos revueltos en abigarrado tropel ${ }^{15}$.

Pero la teología monoteísta de las religiones del Libro sí concibió la figura antropomorfa de un ser único, personalmente responsable del Mal absoluto. Su papel está representado por Satán, cuya maldad le confiere la osadía de desafiar a la propia divinidad. Y por eso la tradición cristiana ha elaborado tantos mitos de estirpe satánica, que como encarnaciones del Maligno sólo buscan hacer el mal, sin respetar ni lo divino ni lo humano. La Reforma acentuó la creencia en el Mal, del que hay que purificarse, y Lutero concibió al cristiano (y a sí mismo) como un Héroe en lucha contra el Mal, encarnado por Satán. También la Contrarreforma desató una cruzada contra el demonio y el infierno, liderada por los jesuítas. Por eso tanto protestantes como católicos compitieron en su inquisitorial caza de brujas contra Magos, Herejes y Brujos de ambos géneros, todos ellos tenidos por monstruos malignos seguidores de Satán.

Y la propia imaginería literaria se dedicó a crear figuras que personificaban el Mal. Un ejemplo característico fue Don Juan, el contrarreformista Burlador de Tirso, que rompe todo compromiso, sólo busca mancillar el honor familiar ajeno y osa desafiar al mismo Dios, retándole a un duelo singular en el que le espera seducir, engañar y burlar. Y tras Don Juan, toda una estirpe de Anti-Héroes literarios, como los violadores, psicópatas sexuales y asesinos múltiples del Marqués de Sade, como el Melmoth de Maturin, como el Drácula de Bram Stoker, como el Maldoror de Lautréamont (Isidore Ducasse), como todos los héroes malditos o fascinados por el Mal que proponen Baudelaire, Huysmans (quien cantó en Là Bas al primer asesino múltiple pederasta 
de la historia: Gilles de Rais, el mariscal de campo de la Doncella de Orléans) o sobre todo Georges Bataille.

$\mathrm{Y}$ hoy en día, la narrativa posmoderna (literaria, cinematográfica o audiovisual) sigue prendida y prendada de esta tradición cultural, pues sus antihéroes predilectos son letales encarnaciones del mal: pederastas, violadores, psicópatas sexuales, asesinos múltiples (serial killers) o auténticos caníbales como Hannibal Lecter, que se nutren de dañar. Se advertirá que todos estos monstruos malignos o matadores son inequívocamente masculinos, y que en ellos su masculinidad resulta indisociable de su sed de mal. Tanto es así que sirven como modelo negativo de referencia respecto al cual poder definir al héroe masculino positivo que protagoniza la narración, y que sin su antagonista maldito resultaría opaco, aburrido y desdibujado como si fuera poco hombre.

Pero el Malvado Monstruo no es sólo el Anti-Héroe, sino que también es el Anti-Padre. En efecto, todos estos personajes literarios de los que vengo hablando, desde Don Juan a Hannibal Lecter pasando por Drácula, son estériles y carecen de progenie: no se les conoce madre, no se casan ni emparejan y desde luego no engendran hijos. $Y$ sobre todo, se dedican especialmente a destruir fisica y moralmente a los padres ajenos, atentando contra su honra familiar. En Don Juan esto resulta explícito, pues su objetivo sistemático es el de manchar el honor familiar de todos los padres a su alcance, sean nobles o plebeyos, seduciendo a sus hijas o esposas para deshonrar su estirpe. Pero no otra cosa hace Drácula, devorando la sangre que simboliza el linaje familiar.

Por lo tanto, si el vértice tanático de la monstruosidad masculina representa la antítesis de la paternidad, esto quiere decir que el otro vértice opuesto ha de simbolizar la paternidad monstruosa, sólo que trascendida y sublimada. En la versión canónica y edulcorada de la patrística cristiana, es la figura del Espírtu Santo, monstruo contra natura en quien se metamorfosea el Padre divino para fecundar a una virgen sin tocarla, engendrando así al Héroe redentor. Y con arreglo a su ejemplo se instituye la figura del sacerdote o padre espiritual, alternativa masculina que se opone al padre de familia sustentador de los hogares con la pretensión de superarle en poder intelectual, arrogándose el monopolio de la educación de sus hijos.

Pero esta redefinición cristiana del monstruo masculino como padre espiritual acogido al patrocinio del Espíritu Santo puede considerarse tardía, y debe ser entendida a su vez como una sublimación de la muy anterior figura del Mago: el auténtico arquetipo que encarna el tercer vértice de la monstruosidad masculina, legítimada por la fuerza 
de la cultura. En efecto, Mago es quien posee un poder mental sobrehumano y sobrenatural, como el que precisamente se atribuye al Espíritu Santo cuando lo infunde a los Apóstoles seguidores de Cristo. Y existió de hecho un personaje histórico contemporáneo, Simón el Mago, que trató de comprar a sus competidores los Apóstoles el poder mental que pretendían haber adquirido del Espíritu Santo: de ahí que, en su honor, se denomine simonía a todo intento de traficar con los oficios que administran o confieren la gracia santificante ${ }^{16}$.

Para Weber, la fuente original del carisma, entendido como don, virtud o gracia sobrehumana, sólo procede de la magia o de la muerte. Así como el carisma del Héroe brota de su conversión en Matador (lo que sólo se produce desafiando y venciendo a un Monstruo, o participando en las masacres perpetradas por una cofradía de guerreros consagrados para la muerte ${ }^{17}$ ), el del sacerdote deriva de su capacidad de representar a un Mago capaz de hacer milagros: sea por sí mismo o en nombre de su Señor (divino o satánico). Este Mago taumatúrgico puede ser un chamán, un brujo o un curandero, en el caso de las comunidades preliterarias. Pero tras la racionalización aportada por la escritura, el Mago se institucionaliza convirtiéndose en Profeta, y aquí destacan por sus consecuencias históricas los Magos fundadores de las tres religiones del Libro: Moisés, Cristo y Mahoma. Sólo después, tras el desencantamiento del mundo derivado del proceso de racionalización, la Magia se seculariza, convirtiéndose en Arte y Ciencia.

Pero no por eso desaparecen los Magos, ni pierden la fuerza carismática que se les atribuye, pues la revolución romántica volvió a enaltecer los poderes infernales que se ocultan tras la ciencia, el arte y la poesía. Y hoy los grandes Magos son los Genios creadores, sean Artistas plásticos, Autores literarios, Poetas malditos o Científicos geniales. En este sentido, el gran Mago moderno por antonomasia es el Fausto cantado por Goethe, como héroe cultural dotado de poderes especiales destinados a transformar el mundo. Pero no hay que olvidar que este Fausto romántico procede del renacentista de Marlowe, y éste a su vez del auténtico Fausto real: un rabelaisiano nigromante que se presentaba como moderna reencarnación del Simón el Mago, haciéndose célebre tras ganarse la enemistad de Lutero, quien lo consideró un emisario de Satán enviado para probarle ${ }^{18}$.

En suma, además del monstruo natural (o monstruo de lascivia) y del monstruo criminal (o monstruo de maldad), hay un monstruo espiritual, o monstruo de la imaginación: es el Mago o genio creador, capaz de redefinir o transformar la realidad. Por eso exhibe tantas variantes por las que también cabe reconocerle (además de las ya 
citadas máscaras del científico, el artista o el autor), dada su capacidad de subvertir la vigente definición de la realidad: como son las figuras del Loco D. Quijote, del Burlador Don Juan o del satírico Karl Krauss ${ }^{19}$, capaces con su sinrazón, su insolencia o su sarcasmo de revelar la impostura del orden vigente. Pues el Humor, ya sea irónico, cínico o absurdo, es el más secreto y eficaz de los poderes mágicos ${ }^{20}$.

\section{Las narrativas masculinas}

Acabada de esbozar mi propuesta de cartografía masculina, donde se contiene el repertorio triangular de sus diversas identidades en juego (de héroe, de padre o de monstruo; y dentro de éste, la del concupiscente, el criminal o el profeta), resta por analizar cómo se integran entre sí, hilando un todo unitario y coherente. De esto se encargan las narrativas de la masculinidad: historias ejemplares que cuentan el modo en que un hombre nace y se hace, trazando un itinerario biográfico en forma de relato dotado de sentido ${ }^{21}$. Y la historia que cuentan suele ser muy simple, pues trata de un Héroe que debe enfrentarse a un Monstruo, su alter ego, en singular combate: si vence, asciende a la categoría de Padre; pero si pierde, se convierte en Monstruo para siempre.

Tal como demostró hace tiempo Vladimir Propp, todo relato presenta siempre la misma forma consecuencial, desarrollada en tres periodos sucesivos: planteamiento, nudo argumental y desenlace ${ }^{22}$. El planteamiento comienza por arrojar al héroe del relato fuera de su hogar originario (en esto insiste Propp), emplazándole para que supere una serie de trabajos iniciáticos, que habrán de convertirle en un hombre adulto. Y cuando esos trabajos empiezan a abordarse surge como encrucijada el nudo argumental. El héroe protagonista ¿elegirá ser un ángel o un demonio?. Así aparece la gran bifurcación. A la derecha, el sacrificado camino que conduce al héroe hacia la legítima paternidad, donde se redimirá a sí mismo si redime a los suyos (es el canónico final feliz propuesto por Propp). Y a la izquierda, la tentadora senda que convertirá al héroe en un monstruo transgresor, traicionando a los suyos. Semejante dilema resulta crucial, pues según cómo se resuelva determinará el curso del relato y el sentido final del desenlace.

$\mathrm{Y}$ semejante estructura narrativa presenta la forma de un rito de paso y transición (rite de passage), cuya secuencia también consta de tres fases análogas ${ }^{23}$ La preliminar o de separación (equivalente al planteamiento del relato), que arranca al neófito fuera de su origen 
inicial. La liminar o de marginación (similar al nudo argumental), que obliga al neófito a extralimitarse, disolviendo su anterior identidad. Y la postliminar o de reincorporación (correspondiente al desenlace), que supone el reingreso dentro de los límites ordinarios, colocando al sujeto en una nueva posición social y atribuyéndole otra identidad.

Pues bien, cada una de estas tres fases aparece vinculada de forma específica a los tres vértices del triángulo masculino que hemos considerado antes. La fase preliminar de planteamiento significa el advenimiento o aparición (epifanía) de la figura del Héroe. La fase liminar o nudo argumental implica el combate ritual entre el Héroe y su alter ego posible, el Monstruo. Y la fase posliminar o desenlace supone o bien la investidura como Padre legítimo o bien la estigmatización irrevocable como Monstruo públicamente reconocido.

Comencemos por la epifanía preliminar, cuando el Héroe aparece, lo que implica el nombramiento del Joven (del Hijo) como candidato a la futura calidad de Hombre. Recordaré que el Héroe es un ser emplazado y puesto a prueba, que debe demostrar su capacidad de superar desafíos. Pero ¿quién lo emplaza, quién le pone a prueba, quien lo desafía? Evidentemente, su familia, es decir, su madre, su padre y demás adultos de referencia. Tanto si lo miramos desde el punto de vista del relato como del ritual, esta fase implica la ruptura con la infancia original, es decir, con la familia natal. Vladímir Propp insiste en que todo cuento comienza por la expulsión del paraíso, es decir, del hogar: del origen natal. Pero alguien ha de expulsar al varoncito de su Jardín del Edén, obligándole a partir al destierro para convertirse en Héroe errante, destinado a atravesar el desierto combatiendo con los múltiples peligros y desafíos que habrán de acecharle. ¿Quién?

Sigmund Freud propuso la figura del Padre como única autoridad moral capaz de obligar al niño a romper con su familia, emplazándole a convertirse en Héroe puesto a prueba. ¿Qué prueba es ésta? La de convertirse algún día en digno sucesor de su padre, lo que le obliga a medirse con él. Es el conocido asesinato figurado del propio padre, pues el Monstruo con el que el Hijo debe combatir, porque le ha desafiado a él, es su Padre. Así sucede en el mito del monstruo Abraham, dispuesto a matar a su hijo Isaac para hacer un hombre de él. Éste es también el mito de Jesús en la Oración del Huerto, que intenta evitar el Calvario al que para redimirle le ha condenado su padre divino. Y asimismo es este el sentido de la Carta a mi padre de Franz Kafka, que se duele de su fracaso al no saber asumir el reto que le lanzó su padre. Pues en definitiva, el Hijo ha de hacer la Voluntad de su Padre, para poder algún día convertirse en Hombre ocupando su lugar. 
Pero la freudiana Nancy Chodorow ha dado la vuelta al argumento de Freud ${ }^{24}$. Quien expulsa al niño de su familiar Jardín del Edén, arrojándole de su lado y emplazándole para que se convierta en Héroe a su pesar, no es el Padre sino la Madre. Ella es quien rompe el cordón umbilical que hasta entonces le vinculaba a su hijo, dejándole solo abandonado a su suerte y exigiéndole que se ponga a prueba, a fin de superarse y demostrar su plena autonomía personal. Es el mito de la Virgen María, que en la cristiana Sagrada Familia es quien mantiene un diálogo moral con su hijo el Niño Jesús, hasta que consigue lanzarlo a la Vida Pública para que se convierta en un Hombre. Es decir, en un Héroe (o un Mago), pues quien hace del Niño un Héroe es su Madre.

Una vez producida esta ruptura preliminar que convierte al niño en Héroe, y con independencia de que haya sido causada por la acción del padre o de la madre (pues siempre cabe pensar en una combinación cooperativa o contradictoria de ambas influencias), comienza la segunda fase liminar. Es la travesía del desierto, cuando Cristo debe enfrentarse a las tentaciones de Satán, hasta acabar por vencerlas y superarse a sí mismo. Esta épica del heroismo masculino exige no sólo destreza virtuosa sino además tensión, violencia y conflictividad, pues se trata de medirse con adversarios más poderosos aceptando su desigual desafío.

En su famoso análisis diferencial del juego de niñas y niños, Carol Gilligan pudo demostrar esta compulsión por la competitividad que caracteriza a los chicos ${ }^{25}$, y que ya no les abandonará cuando lleguen a hacerse hombres hechos y derechos. Es lo que Bourdieu llama los juegos de poder, a los que se entregan los varones heroicos para medirse entre sí compitiendo en las diversas arenas que les enfrentan ${ }^{26}$ : ya sea la política, la economía o la caza de piezas simbólicas (como las sirenas) a las que exhibir como ostentosos trofeos ante sus rivales.

En cualquier caso, el Héroe sabe que está emplazado y puesto a prueba por su entorno, y que no tiene otra salida que asumirlo y luchar en público. Para ello hay que aceptar las reglas de juego que impone la cultura del conflicto y la violencia, convirtiéndose en un Héroe o pareciéndolo. De ahí toda la mitología del espíritu caballeresco, que trasciende la lucha a muerte sublimándola con nobleza, pundonor, magnanimidad, desinterés, lealtad y amor cortés ${ }^{27}$. Lo cual viene a significar, en la práctica, aprender a comportarse como un verdadero Monstruo. Y esto por tres razones al menos.

Ante todo porque el heroismo se demuestra cazando monstruos, como Achab al perseguir a Moby Dick o Teseo al Minotauro, y para poder vencerlos hay que aprender a imitarles, usando sus mismas 
armas contra ellos. Y además, el combate cuerpo a cuerpo te obliga a identificarte con tu adversario, por salvaje que sea éste, pues la pasión del combate enardecido resulta muy contagiosa, dado su emocionante encarnizamiento. De ahí que el cazador se convierta en un depredador contumaz y el guerrero en un matador cruento ${ }^{28}$. Por eso el Héroe se acoge al patrocinio totémico de los Monstruos contra los que debe luchar, según reflejaba la heráldica caballeresca, con sus blasones poblados de águilas, lobos, leones y demás fieras carniceras. $\mathrm{Y}$ no sólo se identifica con los brutos irracionales sino también con los matadores racionales más belicosos: Aquiles, Alejandro, Napoleón.

La segunda razón que contamina de monstruosidad al Héroe es que la fase vital por la que atraviesa, tras romper con su familia y protagonizar ritos de paso que algún le conducirán hacia la madurez adulta, se caracteriza por su radical agonismo compulsivo. Lo hemos visto al analizar los rituales, cuya fase central consiste en la liminaridad, es decir, en la extralimitación. Para comportarse como tal, el Héroe debe entrar en trance, abandonando el orden cotidiano más allá de sus límites o fronteras habituales, lo que implica incurrir en la transgresión de la normativa ordinaria, cayendo en estado de excepción que confiere licencia para extralimitarse y vulnerar todas las leyes.

Como reza el aforismo, en el amor como en la guerra, todo está permitido. De ahí que, mientras experimenta sus efímeros episodios de éxtasis heroico, y hasta tanto regrese a la normalidad tras el combate, el Héroe tiende a convertirse en un verdadero monstruo, en una fiera desatada. Esta propensión a salirse fuera de la realidad, cayendo en un delirio desmedido, está muy bien caricaturizada por la sinrazón del Quijote. Pero es también la que caracteriza a tanto joven violento durante sus ritos de fin de semana, embriagado con monstruosas heroicidades ${ }^{29}$. Por eso resulta conveniente instrumentar antagonismos incruentos, por el estilo del deporte moderno, a fin de desviar, canalizar y sublimar la propensión juvenil a la violencia heroica ${ }^{30}$.

Queda la tercera razón, que hace del Héroe un alter ego del Monstruo, y es la división social en clases, etnias, comunidades y territorios enfrentados. Por eso, dados los multiples cleavages que separan unas identidades colectivas de otras, estableciendo límites infranqueables entre ellas, un mismo agonismo violento le parece a su comunidad la sagrada hazaña de un Héroe redentor mientras para sus vecinos o sus víctimas es el terrible crimen de un Monstruo maligno. Es el caso de la violencia de ETA, que hace de sus ejecutores unos gudaris que se sacrifican por el honor de los suyos, incapaces de reconocer sus monstruosas violaciones de los derechos ajenos ${ }^{31}$. Pues una forma 
de que el Héroe se extralimite es atravesando las fronteras que delimitan su identidad colectiva, y ello implica convertirse en un monstruo agresor, presto a dañar, violar o injuriar la identidad de las comunidades ajenas. De ahí que todo Arcángel de los suyos sea un Satán para los otros.

$\mathrm{Y}$ esta doble faz jánica de ángel y demonio hace del Héroe un personaje ambivalente y ambiguo, dada la disyuntiva moral en la que se debate, sin poder saber muy bien cómo distinguir y separar dentro de sí los dos contradictorios espíritus que anidan en su corazón: el de diablo monstruoso y el de santo redentor. Con ello llegamos a la tercera fase posliminar de reincoporación o desenlace, cuando el Héroe concluye sus trabajos de confrontación. Pues sólo entonces, a toro pasado, cuando la ejecutoria protagonizada ya no tenga ningún remedio, es cuando podrá constatarse cuál ha sido el veredicto y la sentencia de semejante juicio final, si la fatídica condena o la redentora salvación.

El final feliz del relato exige que el Héroe, tras coronar con éxito su aventurada educación sentimental, se convierta a su vez en Padre, superando o igualando a su padre original. Esto implica redimir a los suyos (ésa es la función paterna), lo cual le permite de paso redimirse también a sí mismo, justificando ex post facto los crímenes monstruosos que en la fase heroica se pueda haber cometido. Pero si el Héroe fracasa, y no logra coronar con éxito su obra de redención, entonces quedará condenado a vagar en poder del Monstruo que se ha adueñado de su voluntad. $\mathrm{Y}$ este final trágico también supone una suerte de redención, pues al asumir el castigo que se merece por no haber sabido vencer a su Monstruo interior, el Héroe recupera una cierta dignidad a costa de renunciar a serlo: es la dignidad del loser o perdedor, lo que le convierte en un anti-héroe o héroe maldito . En esta exigencia de final ejemplar o redentor, presente en todo relato, insiste mucho Propp, como única forma de dar sentido ūitario a la narración.

$\mathrm{Y}$ esta necesidad de dotar de sentido final a la lucha del Héroe, ya sea su desenlace feliz o desgraciado, no es sólo un truco retórico, exigido por la coherencia narrativa. Si el Héroe precisa acabar su calvario con dignidad, ascendiendo al papel de Padre o descendiendo al abismo de los Monstruos, es para no caer en el absurdo. Pues son tan arduas e interminables las luchas, trabajos y pruebas que tienen que superar los Héroes que antes o después han de plantearse la pregunta más inquietante: tanto heroismo, ¿para qué? ¿Por puro deber moral, o por mero amor al arte? ¿Qué sentido tiene emprender una carrera de desafíos absurdos, reiterativos e interminable? ¿Acaso el heroismo es una pasión inútil o estéril?: ¿un cuento narrado por un idiota, lleno de ruido y de furia, que no significa nada, por decirlo citando a Macbeth? 
Pues bien, sólo el decidido intento de acceder al status de Padre le confiere sentido y dignididad a la lucha, convirtiéndola en una pasión util y fecunda: es decir, redentora. Éste es el objetivo supremo, cuya búsqueda justifica la vida entera. De ahí que atravesar el paso que conduce a la paternidad sea el momento de la verdad, es decir, la culminación de la previa carrera heroica. Ahora bien, esa culminación puede acabar en fracaso, pues no todos los héroes terminan por convertirse en padres. Muchos son los llamados pero pocos los escogidos. $\mathrm{Y}$ una importante fracción no logra cruzar esa meta final.

Por eso insiste Bourdieu en que todo rito de transición es en realidad una investidura, como sucede con la coronación, el ascenso o la toma de posesión. En efecto, la fase postliminar implica atravesar una línea imaginaria ${ }^{32}$, cuyo trazo semeja la raya de una meta de llegada, situada al final de la carrera que enfrenta a los héroes que compiten entre sí. Pues bien, esa raya ritual es el límite que separa a los Héroes de los Padres, o verdaderos hombres. Antes de cruzarla, los Héroes no son todavía más que medio hombres o aspirantes a futuros hombres enteros, pues entonces aún se hallan en el trance de hacerse, y mientras tanto siguen a medio hacer. Pero en cuanto logran cruzar la raya con éxito, ascienden a la categoría de Padres enteros, es decir, de verdaderos hombres completos, ya del todo hechos y derechos.

¿Y qué sucede con el que pierde la carrera, y no logra cruzar la meta? La culminación del drama siempre implica tres posibles desenlaces. $\mathrm{O}$ bien el Héroe progresa y asciende a la irrevocable categoría de Padre, convertido en todo un hombre. O bien, por el contrario, no logra ascender, cayendo en una regresión interminable. En cuyo caso caben dos alternativas distintas. De un lado, el destierro y el exilio, que le condenan a vagar errante marcado con el estigma de Monstruo y convertido en un mal hombre. Y del otro la cobarde defección, que le hace perder la categoría de Héroe degradándole a la infamante condición del villano convertido en un poco hombre.

\section{El eclipse de los monstruos}

Hasta aquí la genérica morfología estructural de toda narrativa masculina, abstracción hecha de sus diversas manifestaciones concretas, enormemente variables según tiempo y lugar. Pero cabe interrogarse acerca de cuál es su posible tipología, y de cómo ha evolucionado a lo largo del devenir histórico. Por eso, para cerrar este ensayo voy a exponer un sencillo modelo evolutivo, que se desarrolla en tres fases 
al compás del proceso de modernización. Convencionalmente, llamaré a estos tres periodos premoderno, moderno y posmoderno. Pero como el concepto de posmodernidad es polémico, resulta discutible y está muy desprestigiado, si el lector lo desea puede sustituir esta tipología por cualquier otra, como por ejemplo la de tradicional, moderno y de modernidad tardía, contemporánea o avanzada.

A riesgo de caer en la simplificación, este modelo de desarrollo evolutivo podría dibujarse de la siguiente forma. Las narrativas masculinas de tipo tradicional suelen adoptar la forma de tragedia o epopeya, donde los actores son fatalistas porque no cuentan con ninguna libertad de elección, y el destino se les impone desde fuera. En estas formas premodernas, la figura del Padre está muy desdibujada y resulta periférica, representando el único papel formal de telón de cierre o desenlace conclusivo que pone punto final a la relación de los hechos, actuando como zanahoria de recompensa que sólo se recaudará cuando la función acabe: se casaron, fueron felices y comieron perdices.

En cambio, Monstruos y Héroes ocupan el centro absoluto de la narrativa premoderna: en la epopeya, el protagonismo es de éstos, mientras que en la tragedia es de aquéllos. Pero en ambos casos su recíproco antagonismo resulta esencial, aunque la suerte que uno y otra puedan correr no depende de sus méritos respectivos sino del más puro azar. Son los Hados quienes lo deciden todo, y además lo deciden de una vez por todas. Por eso, para estas narrativas, todo está escrito de antemano. Esto hace que sea el planteamiento inicial del relato (el Origen, los Principios, el Pasado), lo que determina todo el curso posterior de la acción ¿Por qué? Sin duda, porque en la premoderna sociedad tradicional la suerte de las personas está predeterminada por la cuna y la casta, pues el trágico destino fatal lo tejen y destejen las tres Moiras, que representan el nacimiento, el matrimonio y la muerte.

En la sociedad estamental, todos los status son adscritos, y se atribuyen en exclusiva por el origen familiar, que condena de por vida a representar el papel de héroe o de villano, con la única alternativa de convertirse en monstruo depredador de la honra familiar. De ahí que se imponga la weberiana ética de las convicciones (o de los principios originarios), que lo deja todo al libre juego aleatorio de las pasiones, donde sólo reina la violencia imprevisible, desencadenada por los ciclos recurrentes de venganza étnica o familiar, allí donde Monstruos y Héroes combaten a muerte. En efecto, la institución central de la ética masculina anterior a 1800 es la venganza o el duelo, que obliga a los hombres a enfrentarse a muerte en defensa de su honor personal 
y familiar: los nobles de acuerdo al código del honor de las reglas de caballeríay los villanos ${ }^{33}$ a garrotazos, como en el fresco de Goya.

Pero todo este monstruoso mundo heroico de rabia y de hierro, de ruido y de furia, donde todos se matan a sangre y fuego, se quiebra entre 1600 y 1700 , cuando se desarrolla lo que Norbert Elias llamó el proceso de civilización ${ }^{34}$, iniciado en las cortes barrocas que reprimieron la violencia de la nobleza guerrera hasta llegar a convertirla en nobleza cortesana, obligada a respetar la naciente opinión pública obedeciendo reglas de etiqueta y cortesía. Desde entonces los Héroes dejan las armas y aprenden a sublimar su conflictivo antagonismo, que se transforma en competición incruenta representada en el gran teatro del mundo ante un crítico público de espectadores vigilantes. Y también los Monstruos se subliman, apareciendo en escena los tres grandes mitos que nacen con el Barroco: Don Juan y Don Quijote, que se burlan del amor cortés parodiando y subvirtiendo las reglas de caballería, y el Mago Fausto, que busca como Don Juan engañar al Destino para forzar su suerte, erigiéndose así, como señala Ian Watt, en los primeros campeones individualistas de la naciente modernidad ${ }^{35}$.

Y a partir de 1700, comienza la era moderna, presidida por la invención de un Nuevo Hombre, capaz de calcular su futuro y de controlar sus pasiones. Los héroes y monstruos del Barroco pierden la partida, abandonan el centro del escenario y pasa al primer plano la figura del Padre burgués, como primer protagonista de la nueva narrativa masculina, que antepone la prosaica defensa del propio interés racional, fundado en la propiedad familiar o empresarial, sobre todas las demás pasiones heroicas, a las que se juzga como ruinosas, estériles o destructivas: o sea como fútiles, perversas y monstruosas.

En un célebre ensayo, Albert Hirschman lo narró muy bien ${ }^{36}$, relatando cómo la Ilustración esperaba que el comercio suavizase la violencia de la lucha por el poder, sustituyendo la conflictividad belicosa por la competencia capitalista. Y en efecto, la nobleza dejó de dedicarse a las armas y a la guerra para pasar a ocuparse de la economía y los negocios. Lo cual exige anticipar el futuro con previsión racional del propio interés, a fin de calcular la mejor inversión productiva. Aparece así la nueva figura moderna del empresario: el Patrón capitalista, que no es sino la modernización burguesa del Patriarca, como nuevo avatar del Padre cabeza de familia.

$\mathrm{Y}$ así convertido en padre padrone, el nuevo héroe de los negocios aprendió a domar, dominar y domesticar sus monstruosas pasiones. En efecto, el valor supremo al que sirve el hombre nuevo es el autocontrol, la moderación, el dominio de sí, la fuerza de voluntad, el 
cálculo del futuro, la constancia perseverante. Precisamente aquellos valores calvinistas que habría de cantar Weber como catalizadores del espíritu del capitalismo, pero que hacia 1800, al hilo de la revolución burguesa, son propagados por la ola de pietismo que invade Europa.

Hacerse hombre exige fuerza de voluntad para dominar y sujetar al monstruo que habita en el corazón de uno mismo, pues como también señaló Weber, recuperando la temática faustiana heredada de Goethe, en el interior de cada uno habita un daimon contradictorio, al que hay que enfrentarse no con heroismo apasionado sino con perseverante disciplina racional, a fin de convertirse en sujeto del propio destino elegido, y ya no en objeto de aciagas fuerzas ajenas, como los héroes arcaicos entregados a los Hados fatídicos ${ }^{37}$. Es el triunfo de la moderna ética de la responsabilidad personal, que para Weber se opone a la premoderna ética de las convicciones. Y a resultas de este movimiento pietista en pro del autocontrol masculino surge la campaña que reclama la abolición de los duelos, que aún tardará un siglo en triunfar, desde que logra su primer éxito con la pionera prohibición inglesa de $1811^{38}$.

Pero lo que hizo posible domesticar en mayor medida a Héroes y Monstruos fue su anclaje en la estructura social ${ }^{39}$, que les permitió convertirse en Padres vitalicios de por vida. En efecto, la revolución burguesa instauró el mercado de trabajo para profesionales y asalariados como institución central de la modernidad, y una gran mayoría de varones pudo hallar empleo estable vitalicio con el suficiente nivel de ingresos asegurados como para sustentar una familia y educar a sus hijos. Y este anclaje en la estructura social, hecho posible por la industrialización, se generalizó a partir de 1900 con la aparición del fordismo, el incremento de la salarización, la extensión de la enseñanza obligatoria y la elevación del nivel de capital humano, lo que acabó por profesionalizar a los hombres adultos y maduros convirtiéndolos en candidatos vocacionales a Padres responsables de sí y de los suyos.

Así se invirtió el sentido de la temporalidad masculina. Si en la sociedad premoderna la narrativa biográfica estaba orientada hacia el pasado, porque el destino de los hombres aparecía predeterminado por su origen familiar, en la sociedad moderna, por el contrario, la nueva narrativa burguesa pasó a estar orientada hacia el futuro, pues el destino personal parecía poder autodeterminarse en función del propio mérito y esfuerzo. Es la ética moderna del hazte a tí mismo, que impulsa a construir individualmente el propio destino, por oposición a la ética tradicional del conócete a tí mismo, que recomendaba identificarse con los propios orígenes infantiles, familiares y étnicos. 
Y este desplazamiento del nudo argumental narrativo hacia el futuro permitió realzar la figura del Padre hacia la que conduce la aventurada carrera del Héroe, pasando a erigirse en centro de gravedad del relato. De este modo, tragedia y epopeya quedaron relegadas y cayeron en el desuso, como narrativas predeterminadas por los antepasados, pasando a triunfar la novela como nueva forma dominante, donde el curso argumental de la narración sólo puede explicarse por la busca del mejor desenlace. Es la novela decimonónica de los héroes románticos que construyen a solas su propio destino, entre cuyos ejemplos destacan El rojo y el negro de Stendhal, La educación sentimental de Flaubert y Bel Ami de Maupassant. Y esta narrativa burguesa fue teorizada en sentido weberiano por Georg Lukács ${ }^{40}$, al mostrar cómo el héroe narrativo construye su propia salvación personal.

Esta orientación hacia el futuro resulta esencial, pues es la que permite al héroe del relato responsabilizarse de sus compromisos con los demás: sean amorosos y familiares o políticos. Y de aquí se deriva el enaltecimiento de la figura del Padre, quien no es un mero sustentador del hogar sino algo mucho más importante: un auténtico empresario familiar (como en la saga de Los Buddenbrock, de Thomas Mann) capaz de asegurar la futura prosperidad de todos los suyos, de quienes se hace cargo asumiendo plena responsabilidad personal por ellos, como si fuese una encarnación terrena de la Providencia divina.

En suma, el hombre moderno está volcado en la construcción personal de su propio destino y el de los suyos. Lo cual exige tener un futuro asegurado por delante, para poder hacer planes a largo plazo en busca del mejor desenlace. Y esto no era posible en la sociedad premoderna, donde los Héroes tenían pasado (familiar) pero no tenían futuro, enfrentados como estaban a una muerte inminente a manos de Monstruos propios o ajenos, por lo que su destino era totalmente impredecible e incierto $\mathrm{Y}$ semejante incertidumbre de futuro les condenaba a vagar errantes en busca de aventuras autojustificatorias, como hace compulsivamente Don Quijote. En cambio, el hombre moderno ya no es un incierto héroe errante, pues él sí tiene su propio destino asegurado por la certidumbre del futuro que le proporciona su carrera escolar y laboral, académica y profesional. De ahí que pueda fundar su propia familia, responsabilizarse de su destino común a largo plazo y comprometerse vitaliciamente con ella.

Ahora bien, esto sólo fue posible mientras la industrialización permitió asignar a los varones una posición social fija y estable, vinculada a un empleo vitalicio en el oficio o la profesión vocacionalmente elegidos por cada cual. Pues así, una vez anclados en su propio empleo estable, el obrero y el profesional podían fundar familias vitalicias para com- 
prometerse responsablemente con ellas. Y este anclaje laboral o profesional, que les arraigaba de por vida en la estructura social, les permitía tanto convertirse en Padres providenciales y proveedores como domesticar a su Monstruo interior, sujetándolo de por vida a su propio hogar doméstico. Pues, en realidad, un Padre no es más que un Héroe doméstico, cuya fidelidad o lealtad vitalicia le asemeja a un dócil Monstruo, domesticado a domicilio.

Por eso cabe plantear la duda de si semejante domesticación del Monstruo masculino, y el auge paralelo de la figura del Padre, no serán sólo espejismos pasajeros, dado que parecen ser excesivamente dependientes de las pasadas coyunturas económicas que garantizaban una boyante estabilidad laboral. Con esto llegamos a la tercera fase posmoderna antes anunciada, iniciada con el último tercio del siglo XX, cuando el advenimiento de la bautizada por Daniel Bell sociedad posindustrial, ahora reforzada por el acceso de las últimas novedades traídas por lo que se llama globalización, nueva economía y sociedad de la información, parecen estar erosionando gravemente (si es que no destruyendo irreversiblemente) la necesaria estabilidad laboral.

En efecto, hoy crece de forma al parecer imparable lo que para sus apologistas es flexibilidad laboral mientras para sus detractores es precariedad del empleo. En cualquiera de ambos casos, la estabilidad laboral se está perdiendo quizá para siempre. Lo cual tiene ingentes consecuencias sobre la identidad personal y sobre la estabilidad familiar, en términos tanto de auge del divorcio como de retroceso de la nupcialidad ${ }^{41}$. Y es que, cuando el anclaje en la estructura social se hace contingente y precario, como sucede al aumentar la flexibilidad laboral, también entonces los vínculos familiares se vuelven inestables, contingentes y precarios. En consecuencia, también la propia identidad se resiente: Tanto para Freud como para Weber, Amor y Trabajo constituyen la doble columna vertebral de la trayectoria biográfica, como doble sede de la madura identidad adulta ${ }^{42}$. Pero cuando el Trabajo se fragmenta y disuelve, también el Amor ha de hacerlo. Y sin constancia laboral y amorosa, la identidad se vuelve contingente ${ }^{43}$.

Así es como se produce el declive del Padre y el retorno de los Monstruos. La presente inestabilidad de la estructura social hace que cada vez sea más dificil seguir manteniendo domesticados a los monstruos, convirtiéndoles en padres vitalicios a tiempo completo. De hecho, algunos sostienen que sucede al revés, pues se estaría incrementando la llamada ausencia del padre, consistente tanto en una pérdida de vocación masculina por la paternidad (constatable por el auge de los nuevos solteros y la doble caída de la fecundidad y la nupcialidad) 
como por una creciente deserción de las responsabilidades paternas contraídas: abandono del hogar, divorcio, desvinculación de los hijos, impago de las pensiones alimenticias o compensatorias, etc. ${ }^{44}$.

Ahora bien, como narra la Odisea de Ulises, cuando el Padre se ausenta los Monstruos se hacen presentes, asediando a esposas, madres e hijos. En efecto, cada vez parece haber más indicadores que anunciarían el retorno de una arcaica monstruosidad masculina que creíamos haber superado tras doscientos años de modernidad: violencia de género, maltrato doméstico, violaciones, acoso sexual, agresiones sin cuento. $\mathrm{Al}$ mismo tiempo, y como efecto perverso de la misma ausencia del padre que desestructura los hogares familiares, crecen el fracaso escolar, la violencia adolescente, la drogadicción, la delincuencia juvenil, el desemplep crónico y nuevos estilos de vida insalubres, arriesgados y autodestructivos. Todo parece indicar, en suma, que la domesticación de los monstruos obrada por la modernidad industrial no fue permanente e irreversible sino tan sólo un eclipse pasajero, del que ahora estaríamos saliendo pues comenzamos a percibir signos que parecen anunciar el próximo regreso de los monstruos.

Y esto es así porque aquel anclaje fijado de por vida en la estructura social, que hizo posible la industrialización, está siendo sustituido por un nuevo desanclaje estructural, asociado al incremento posindustrial de la precariedad laboral, que obliga a los varones a navegar a la deriva como Ulises, errando por su vida entre el desconcierto y la incertidumbre mientras incumplen sus compromisos amorosos y familiares, abandonan a sus hijos, se pierden entre los brazos de dudosas sirenas y se disponen a imitar de nuevo a los Monstruos ${ }^{45}$. Pues ahora, como ya no tienen un futuro asegurado como Padres maduros, y flotan en el vacío sin ningún anclaje estructural capaz de sujetarles al hogar, prefieren regresar al espejismo pueril de creerse Héroes inmaduros, aun a riesgo de caer en estériles monstruosidades. Y así es como los Monstruos que la modernidad había domesticado para convertirlos en Padres residentes comienzan de nuevo a asilvestrarse, emancipándose de sus cadenas familiares para recobrar su primera naturaleza indómita, que ya se creía olvidada pero que ahora regresa más salvaje que nunca, moviéndoles a conducirse como resabiados Monstruos cimarrones.

\section{Notas}

1 Elisabeth Badinter: XY: La identidad masculina, Alianza, Madrid, 1993.

2 Enrique Gil Calvo: El nuevo sexo débil. Los dilemas del varón posmoderno, Temas de Hoy, Madrid, 1997. 
3 Jon Elster: Egonomics, Gedisa, Barcelona, 1997.

4 Judith Butler: Gender Trouble. Feminism and Subversion of Identity, Routledge, Nueva York, 1990.

5 Jean Flori, Caballeros y caballería en la Edad Media, p. 205, Paidós, Barna, 2001.

6 Claude Lévi-Strauss: Lo crudo y lo cocido, F.C.E., México, 1968.

7 Enrique Gil Calvo: Medias miradas. Un análisis cultural de la imagen femenina, Anagrama, Barcelona, 2000.

8 Geoges Dumézil: Heur et malheur du guerrier. Aspects mythiques de la fonction guerrière chez les Indo-Européens, Paris, 1969 (hay traducción al castellano en Editorial Siglo XXI). Fernando Savater: La tarea del héroe, Taurus, Madrid, 1981.

9 Joan Frigolé: Un hombre. Género, clase y cultura en el relato de un trabajador, Muchnik, Madrid, 1997.

10 Jean Flori, op. cit., p. 200.

11 Ramón Ramos: “Jano y el ornitorrinco», en Pérez-Agote y Sánchez-Yncera (eds.), Complejidad y Teoría Social, CIS, Madrid, 1996. Donna Haraway: Ciencia, "cyborgs» y mujeres. Cátedra, Madrid, 1995. Y de la misma autora posfeminista: "Las promesas de los monstruos", Política y Sociedad, n 30, Madrid, 1999.

12 Mary Douglas: Símbolos naturales, Alianza, Madrid, 1988. Victor Turner: El proceso ritual, Taurus, Madrid, 1988.

13 René Girard: El chivo expiatorio, Anagrama, Barcelona, 1982.

14 César Aira: «Dos notas sobre Moby Dick, «Babelia (El Pais), p. 32, 12-05-01.

15 Aurelio Pérez Jiménez y Gonzalo Cruz Andreotti (eds.): Seres intermedios. Ángeles, demonios y genios en el mundo mediterráneo, Ediciones Clásicas, Madrid, 2001.

16 E. M. Butler: El mito del mago, Cambridge University Press, Madrid, 1997.

17 Stefan Breuer: Burocracia y carisma. La sociología política de Max Weber, Edicions Alfons el Magnànim, Valencia, 1996.

18 Ian Watt: Mitos del individualismo moderno, Cambridge Univ. Press, Madrid, 1999.

19 Bernd Marizzi y Jacobo Muñoz (eds): Karl Kraus y su época, Trotta, Madrid, 1998.

20 Peter Berger: Risa redentora. La dimensión cómica de la experiencia humana, Kairós, Barcelona, 1999.

21 Enrique Gil Calvo: Nacidos para cambiar. Cómo construimos nuestras biografías, Taurus, Madrid, 2001.

22 Vladímir Propp: Morfología del cuento, Akal, Madrid, 1998.

23 A. Van Gennep: Los ritos de paso, Taurus, Madrid, 1986. Victor Turner, op. cit.

24 Nancy Chodorow: El ejercicio de la maternidad, Gedisa, Barcelona, 1984.

25 Carol Gilligan: La moral y la teoría, F.C.E., México, 1985.

26 Pierre Bourdieu: La dominación masculina, Anagrama, Barcelona, 2000.

27 Jean Flori, op. cit.

28 Barbarah Ehrenreich: Ritos de sangre. Orígenes e historia de las pasiones de la guerra, Espasa, Madrid, 2000.

29 E. Gil Calvo: "La complicidad festiva. Identidades grupales y ritos de fin de semana", revista De Juventud, $\mathrm{n}^{\circ}$ 37, Madrid, 1996.

30 Norbert Elias y Eric Dunning: Deporte y ocio en el proceso de la civilización, F.C.E., Madrid, 1992.

31 Joseba Zulaika: Violencia vasca: metáfora y sacramento, Nerea, Madrid, 1988. 


\section{Familia e identidad masculina}

32 Pierre Bourdieu: "Los ritos de paso como actos de institución", en J. Pitt-Rivers y J. G. Peristiny (eds.), Honor y gracia, Alianza, Madrid, 1993.

33 V. G. Kiernan: El duelo en la historia de Europa, Alianza, Madrid, 1992. Véase también Jean Flori, op. cit., y George. Mosse, citado en nota 38.

34 Norbert Elias: La sociedad cortesana, F.C.E., Madrid, 1982.

35 Ian Watt, op. cit.

36 Albert O. Hirschman: Las pasiones y los intereses, Península, Barcelona, 1999.

37 José María González García: Las huellas de Fausto. La herencia de Goethe en la sociología de Max Weber, Tecnos, Madrid, 1992.

38 George L. Mosse: La imagen del hombre. La creación de la moderna masculinidad, Talasa, Madrid, 2001.

39 Debo esta precisa expresión al profesor Salustiano del Campo, quien la sugirió en su comentario público a mi intervención oral durante el seminario de la UIMP.

40 Georg Lukács: Teoría de la novela, Siglo Veinte, Buenos Aires, 1966.

41 Richard Sennet: La erosión del carácter. Las consecuencias personales del trabajo en el nuevo capitalismo, Anagrama, Barcelona, 2000. Martin Carnoy: El trabajo flexible en la era de la información, Alianza, Madrid, 2001.

42 Neil Smelser y Erik Erikson (eds.): Trabajo y amor en la edad adulta, Grijalbo, Barcelona, 1982.

43 Enrique Gil Calvo: Cómo construimos nuestras biografías, op. cit.

44 Lluís Flaquer: La estrella menguante del padre, Ariel, Barcelona, 1999.

45 Enrique Gil Calvo: $E l$ nuevo sexo débil, op. cit. 
Fe de erratas

\author{
En el artículo de D. Enrique Gil Calvo \\ titulado "Familias fallidas y trabajo materno", \\ de la página 283 a la 299
}

las cabeceras dicen: "Tecnología y Sociedad. La nueva tarea del héroe" y deben decir: "Familias fallidas y trabajo materno". 